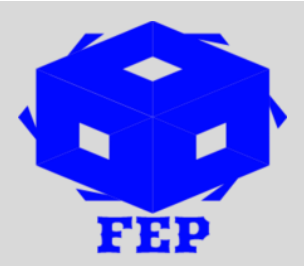

\title{
AN EXAMINATION OF RECENT TRENDS, COMPOSITION AND TRADE INTENSITY OF NIGERIA-BRAZIL BILATERAL RELATIONS
}

\author{
Kabiru Hannafi Ibrahim ${ }^{1} \&$ Dyah Wulan Sari $^{2}$
}

${ }^{1}$ Department of Economics, Universitas Airlangga, Surabaya, Indonesia, \& Department of

Economics, Federal University, Birnin Kebbi, Nigeria

${ }^{2}$ Department of Economics, Universitas Airlangga, Surabaya, Indonesia

*Corresponding Author: Kabiru Hannafi Ibrahim

Corresponding Author Email: hannafi.kabiru@yahoo.com

Article Received: $16-07-19$

Accepted: $25-08-19$

Published: 05-09-19

Licensing Details: Author retains the right of this article. The article is distributed under the terms of the

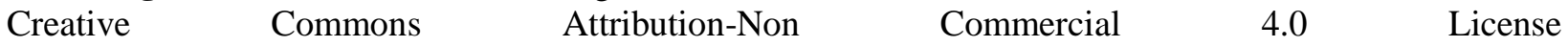
(http://www.creativecommons.org/licences/by-nc/4.0/) which permits non-commercial use, reproduction and distribution of the work without further permission provided the original work is attributed as specified on the Journal open access page.

\begin{abstract}
This paper examines the trends, composition and trade intensity of Nigeria-Brazil bilateral trade relations for the period 2000-2017. Tables, graphs, and trade intensity index were employed. The results indicate that Nigeria's trade with Brazil has significantly recorded impressive growth. However, the share of major products exported to Brazil over the period remained insignificant with the exception of mineral fuels. The results further show that the share of major products imported from Brazil is significant, indicating that Brazilian exports to Nigeria are more diversified than that of Nigeria's export to Brazil. The trade intensity index indicates high trade intensities between the countries and the high possibility of increasing bilateral trade flow. Based on these findings, the study recommends the need for Nigeria's export to be restructured in order to reduce the prevailing role of mineral fuels to Nigeria's exports through diversification and identification of new export opportunities in Brazilian markets.
\end{abstract}

Keywords: Trade, bilateral relations, trade intensity index, Nigeria, and Brazil 


\section{INTRODUCTION}

Nigeria-Brazil bilateral relations started in 1960 with the establishment of diplomatic relations between the two countries. During the period, the two countries relation was strictly meant for the enhancement of cultural and historical activities rather than trade. The relationship between the two countries has been stagnant until the time when Brazilian President Luiz Inacio Lula de Silva enforced Pro African Foreign Trade Policy 2003-2010. This inspired bilateral trade relations between the two countries and yielded unprecedented benefits to both countries. Nigeria and Brazil were among the fiddle players in the world and their respective continents in term of size, trade, and population. Nigeria is the largest in the whole African continent in term population and economic size so also Brazil in South America (International Monetary Fund, 2018). Hence, this indicates that there exist high trade opportunities and a large market for the export of both countries.

Nigeria is one of Brazil's major trading partners in the African continent with a trade value of $\$ 980$ million in 2000 which increased to $\$ 6.79$ billion in 2010 . Nigeria-Brazil bilateral trade records all-time high in 2013 with a trade value of $\$ 10.52$ billion. Over the last one and half decade Nigeria-Brazil trade records a tremendous increase. The rise of the Brazilian economy and the rising population of Nigeria and its abundant natural, mineral and human resources are what made the two countries to record huge bilateral trade. Nigeria alone accounted for more than half of all Brazilian imports from Africa in 2010 (Vincent, 2013). Nigeria is Brazil's 12 ${ }^{\text {th }}$ largest trading partner and Brazil is Nigeria's $3^{\text {rd }}$ largest trading partner and also number three trading partner in terms of crude oil import (UNCOMTRADE, 2018). Nigeria's imports from Brazil includes vehicles and spare parts, machinery, chemicals products, rice, sugar, paper, aircrafts iron and steel among other things while its exports to Brazil are mostly crude oil and other primary products (Garrick, 2013; Uncomtrade, 2018).

Despite a number of commodities with which Nigeria is importing from Brazil, the balance of trade between the two countries have been in favor of Nigeria, this is attributed to the role of crude oil in Nigeria's export (Garrick (2013). In order to strengthen their bilateral relationship in 2013, a bilateral commission was set up to enhance Nigeria and Brazil cooperation in areas of trade, with emphasis on agriculture covering sugar and sugarcane and other areas such as investment in mining, automobile, infrastructure, energy, finance, and food security (Mthuli et al, 2011).

In spite of growing trade relations between Nigeria and Brazil, empirical studies have not been conducted in the area. The only exception is the study by (Ibrahim and Sayuti, 2017a), which analyzed the extent to which Nigeria's export supply match with Brazil's import demand. Other studies related to the current study include (Ibrahim and Shehu 2016; Ibrahim, 2015; Ibrahim and Dilfraz 2014; Idris and Chukwuka, 2014; Ibrahim and Iorember 2018; Ibrahim and Sayuti, 2017b). Most of the existing studies conducted on Nigeria-Brazil trade relations were nonempirical. The only exception was (Abiodun, 2011b) that worked on Nigeria's trade with a trading bloc comprising Brazil, Russia, India, China, and South-Africa (BRICS), of which Brazil is among. This constitutes a gap in the literature that this study would attempt to fill. This has also called for the need to conduct a study on Nigeria-Brazil bilateral trade. 
The objective of this paper is to examine the trends, composition, and intensity of Nigeria-Brazil trade relations. To achieve the foregoing, the rest of the paper is structured into four sections. The next section presents the literature review. Section three discusses the methodology. Section four presents results and discussion while section five offers concluding remarks and policy recommendations.

\section{LITERATURE REVIEW}

\section{a. Theoretical Review}

One of the oldest trade theories which have remained in modern thinking even today is mercantilism (1500-1800). The theory held that countries can increase their wealth holding by promoting exports and discouraging imports. Most countries in the world today, were favoring exports and discouraging imports through the use of protectionist trade policies aim at generating trade surplus through an accumulation of reserve. Adam Smith (1776) saw the need for countries to increase trade through market forces, and that government policy should not regulate trade in any way. To Smith, countries can create a trade surplus if they can produce and export most cheaply. In the early part of the 19th century David Ricardo (1817), proposes a theory of the gains from trade also known as comparative advantage theory which centered on the relative opportunity cost of production rather than absolute cost advantage. Ricardo theory neglects the role of demand in trade theory until J.S Mill that introduced "Reciprocal Demand" which was later advanced by Alfred Marshall (Sunanda, 2010). The Heckscher-Ohlin model of free trade doctrine and later Samuelson known as HO models have emphasized the role of factor endowment based, as against the Ricardian skill or technological based (Sunanda, 2010).

The theoretical expectation of these theories is that countries at large will gain from bilateral and multilateral trade liberalization. Bilateral and multilateral trade liberalization can be either in the form of inter-industry trade or intra industry trade. Inter-industry trade is a trade in different industries by two or more countries. The level of countries engaged in this kind of trade is dependent on their comparative advantage. Intra-industry trade is a trade in similar products by countries which the Heckscher-Ohlin model fails to explain. The model states that countries should export abundant resource products and import scarce resource products and intra industry trade involves the use of the same resources.

It is against this background that this study would examine Nigeria's bilateral trade relations with Brazil using trends analysis and trade intensity index in order to measure the strength of their bilateral trade relations.

\section{b. Empirical Review}

A number of studies have examined Nigeria's trade relations with its trading partners with little attention to Nigeria's trade relations with Brazil which presently is among its major trading partners. In this vein, (Ibrahim and Sayuti, 2017a) examined the comparative advantage between Nigeria and Brazil and measures the extent to which Nigeria's export supply match with Brazil's import demand. The result showed that Nigeria can only competitively export few commodities compared to Brazil and evidence from trade complementarity reveals the existence of a partial 
match between Nigeria's exports supply and Brazil's imports demand. (Ibrahim and Iorember, 2018) have examined both products and sectoral wised comparative advantage in Nigeria-China trade relations. Their study found that Nigeria has a long period comparative advantage in raw materials and mineral fuels export with robust export competitiveness and can export these products to China while China can export to Nigeria mostly manufactured, capital and consumer goods with low exports competitiveness. Their study further revealed that from 1988-2017, Nigeria only partially meets $32.61 \%$ of Chinese import demand from Nigeria, while China moderately meets $57.40 \%$ of Nigeria's import demand from it. (Ibrahim and Shehu 2016; Ibrahim 2015; Ibrahim and Dilfraz, 2014) studies revealed that Nigeria's exports to India are less diversified than that of India's export to Nigeria and major products imported from India over the period 2000-2014 accounts for higher significant share unlike the case of Nigeria's export to India. (Loius and Adewuyi, 2011; Idris and Chukwuka, 2011) showed that Nigeria's trade with West African countries is limited by similar or non-complementary production structures as agricultural dominates the GDP of most countries within the sub-region. (Walther et al., 2012) identified seven important products that are mostly imported and re-exported along the Niger, Benin and Nigeria's borders to include cigarettes, cereals, and flour, used clothing, oil, used vehicles, textile, and building materials. Similarly, (Mombert and Francic, 2012) found that trade between Nigeria and Ghana was lagged behind as a result of a lack of implemented and regulatory reforms, informal payments, delays among many others.

(Ogunkola, 1998) conducted a study and used a gravity model which shows that there are high trade potentialities to be realized by relaxing barriers to trade within the West African sub-region as shown or predicted by the gravity model. (Abraham and Adekola, 2014) conducted a study to determine the impact of regional economic integration on the growth of Nigerian economy the result showed that import and balance of trade are positively related to a gross domestic product while export has a negative relationship with the gross domestic product. (Abiodun, 2011a) also conducted a study to examine the strength of Nigeria's bilateral trade relations with emerging global powers which include countries such as Brazil, Russia, India, China and South-Africa (BRICS). The study showed that Nigeria's relations with the emerging global powers, more specifically Brazil is influenced by its internal, local as well as its domestic policy, the international policy of the emerging global powers and Nigeria's abundant human, natural and economic resources. (Rakesh et al., 2012) analyzed the changes in bilateral trade flow between India and African countries including Nigeria. The results of the study showed that there is rising trade opportunities in pharmaceuticals except in the east African region. (Sabyasachi and Nuno, (2013) examined the impact of the common border, political globalization, economic size, and cultural proximity on India's bilateral trade flow with its major twenty trading partners including Nigeria. The result revealed that economic size of India's trading partners, common border, political globalization, and cultural proximity are both positively and significantly influencing India's bilateral trade flows with its twenty largest trading partners including Nigeria.

From the foregoing, the only existing empirical study that focused on Nigeria-Brazil trade relations is that of (Ibrahim \& Sayuti, 2017a) which examined the comparative advantage of 
twenty major product categories exported between Nigeria and Brazil using Revealed comparative advantage index (RCA) and measure the extent to which Nigeria's export supply match with Brazil's import demand. To this end, it is imperative to analyze the trends, composition and trade intensity between Nigeria and Brazil before any further empirical study.

\section{METHODOLOGY}

The methodology adopted for the analysis was based on the specific objective which the study focused to accomplish. Tables and Graphs are used to analyze the trends and composition of Nigeria-Brazil trade. The trends analysis is important in depicting the time movement in trade especially imports and exports for the study period. This analysis enabled us to determine the trends in Nigeria and Brazil trade (imports and exports) as well as the trends in the growth rate of their trade in order to know the past performance of their trade from the period 2000-2017.

The trade intensity index (TII) is used to find the relative importance of Nigeria-Brazil trade of both import and export. The index focused on bilateral trade flow and also served as a measure of relationship or intimacy between Nigeria and Brazil. Trade intensity index is the share of the country's trade with its bilateral trading partner relative to the share of the world's trade with such trading partner.

The trade intensity index (TII) between Nigeria and Brazil is given by the following formula;-

$$
\mathrm{TII}_{\mathrm{nb}}=\frac{\underline{X}_{\mathrm{nb}} / \underline{X}_{\mathrm{nt}}}{\mathrm{X}_{\mathrm{wb}} / \mathrm{X}_{\mathrm{wt}}}
$$

Where: - $\mathrm{TII}_{\mathrm{nb}}=$ is the trade intensity index between Nigeria and Brazil,

$\mathrm{X}_{\mathrm{nb}}=$ Nigeria's export to Brazil,

$\mathrm{X}_{\mathrm{wb}}=$ World's export to Brazil,

$\mathrm{X}_{\mathrm{nt}}=$ Nigeria's total exports,

$\mathrm{X}_{\mathrm{wt}}=$ World's total exports.

The trade intensity index can also be divided into export intensity index (EII) and import intensity index (III), which can be calculated as;-

$$
\mathrm{EII}_{\mathrm{nb}}=\frac{\mathrm{X}_{\mathrm{nb}} / \mathrm{X}_{\mathrm{nt}}}{\mathrm{M}_{\mathrm{bt}} /\left(\mathrm{M}_{\mathrm{wt}}-\mathrm{M}_{\mathrm{nt}}\right)}
$$

Where: - $\mathrm{EII}_{\mathrm{nb}}=$ Nigeria's export intensity index with Brazil,

$\mathrm{X}_{\mathrm{nb}}=$ Nigeria's export to Brazil,

$\mathrm{X}_{\mathrm{nt}}=$ Nigeria's total exports,

$\mathrm{M}_{\mathrm{bt}}=$ Brazil's total imports,

$\mathrm{M}_{\mathrm{wt}}=$ World's total imports,

$\mathrm{M}_{\mathrm{nt}}=$ Nigeria's total imports.

$$
\mathrm{III}_{\mathrm{nb}}=\frac{\mathrm{M}_{\mathrm{nb}} / \mathrm{M}_{\mathrm{nt}}}{\mathrm{X}_{\mathrm{bt}} /\left(\mathrm{X}_{\mathrm{wt}}-\mathrm{X}_{\mathrm{nt}}\right)}
$$

Where: - III $_{\mathrm{nb}}=$ Nigeria's import intensity with Brazil, $\mathrm{M}_{\mathrm{nb}}=$ Nigeria's import from Brazil,

$\mathbf{M}_{\mathrm{nt}}=$ Nigeria's total imports,

$\mathrm{X}_{\mathrm{bt}}=$ Brazil's total exports, 
$\mathrm{X}_{\mathrm{wt}}=$ World's total exports,

$\mathrm{X}_{\mathrm{nt}}=$ Nigeria's total exports.

The index if computed will lie between zero and infinity (i.e. 0 to $\infty$ ). A high trade intensity index (TII) shows a strong bilateral trade relationship between Nigeria and Brazil while low trade intensity index (TII) shows a weak bilateral trade relationship between the countries. For the export intensity index (EII), an index of greater than one implies a better export possibility from Nigeria to Brazil while an index of less than one implies a weak export possibility from Nigeria to Brazil. Likewise, the import intensity index (III) is the reverse case of export intensity index (EII). In other words, export and import intensities show the relative importance of Brazil to Nigeria in terms of Brazil's demand for Nigeria's exports and the relative importance of Nigeria to Brazil in terms of Nigeria's demand of Brazil's goods.

\section{RESULTS AND DISCUSSION}

\section{a. Trends analysis of Nigeria-Brazil Trade}

It is important to look at the past performance of Nigeria's export and import to and from Brazil for the periods covered under this study, this is much more possible through the trends analysis of Nigeria-Brazil trade.

Trends in export, import, total trade and trade balance

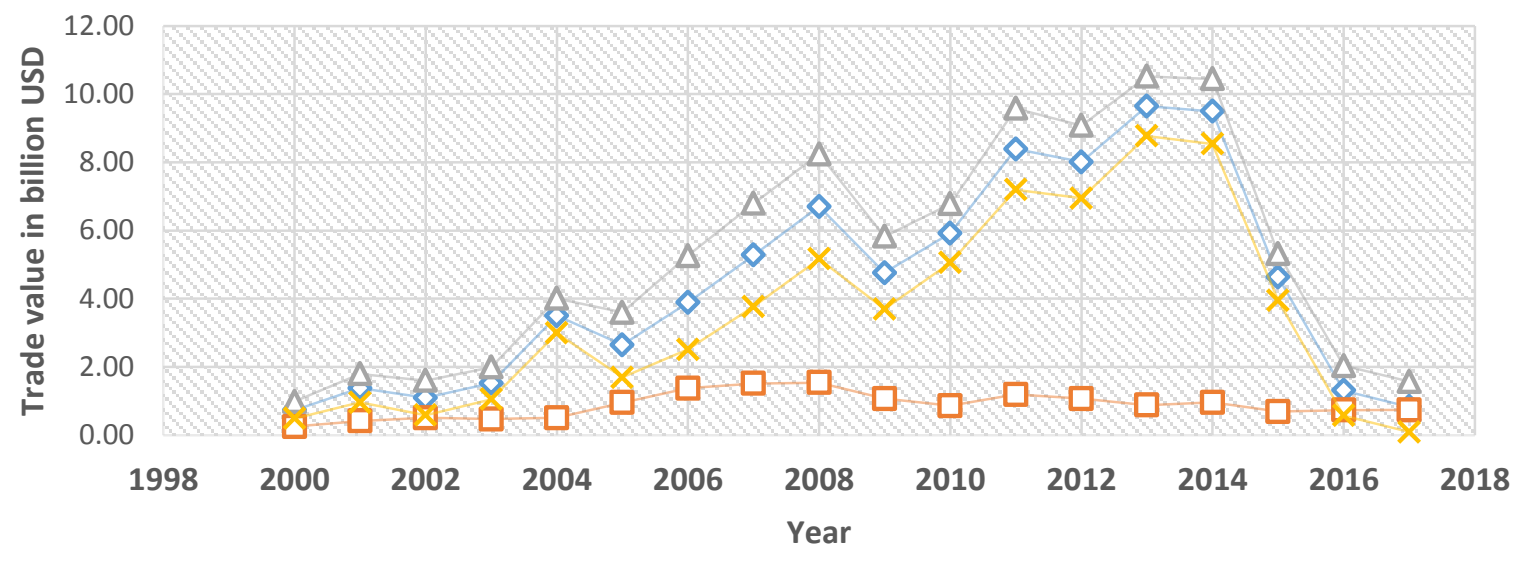

$\diamond$ Nigeria's export to Brazil in billion USD

Nigeria's import from Brazil in billion USD

$\triangle$ Nigeria-Brazil total trade in billion USD

$x$ Nigeria-Brazil trade balance in billion USD

Figure 1: Trends in Nigeria-Brazil Trade 2000-2017.

Source: Authors' Computation from UNCOMTRADE Statistics dated 21/10/2018.

Figure 1 shows the trends in Nigeria's trade with Brazil for the periods 2000-2017. Nigeria's trade with Brazil has recorded a significant increased from 2000-2014 despite the fact that there was major declined from 2015-2017. The main reason for such remarkable/phenomenal increased in export is as a result of the fact that Brazil has enforced Pro African Foreign Policy in 2002 which began to show the symptom of progress on its trade with Nigeria in these years. Despite trade agreement which is between Nigeria and Brazil in 2013, trade with Brazil declined in the year 2015-2017. This decline in total trade was as a result of the export decline in the year 
2015-2017 which are mostly made up of crude oil, petroleum and gases export, and now Nigeria's oil export is directed toward India, United States, Spain, Netherlands, and South Africa leaving Brazil behind the topmost export destinations. Nigeria-Brazil bilateral trade relation is highly strengthened by Nigeria's export to Brazil this is because, Nigeria exports more than it imports from Brazil throughout the periods 2000-2017, as such the balance of trade have been in favor of Nigeria for the whole periods 2000-2017.

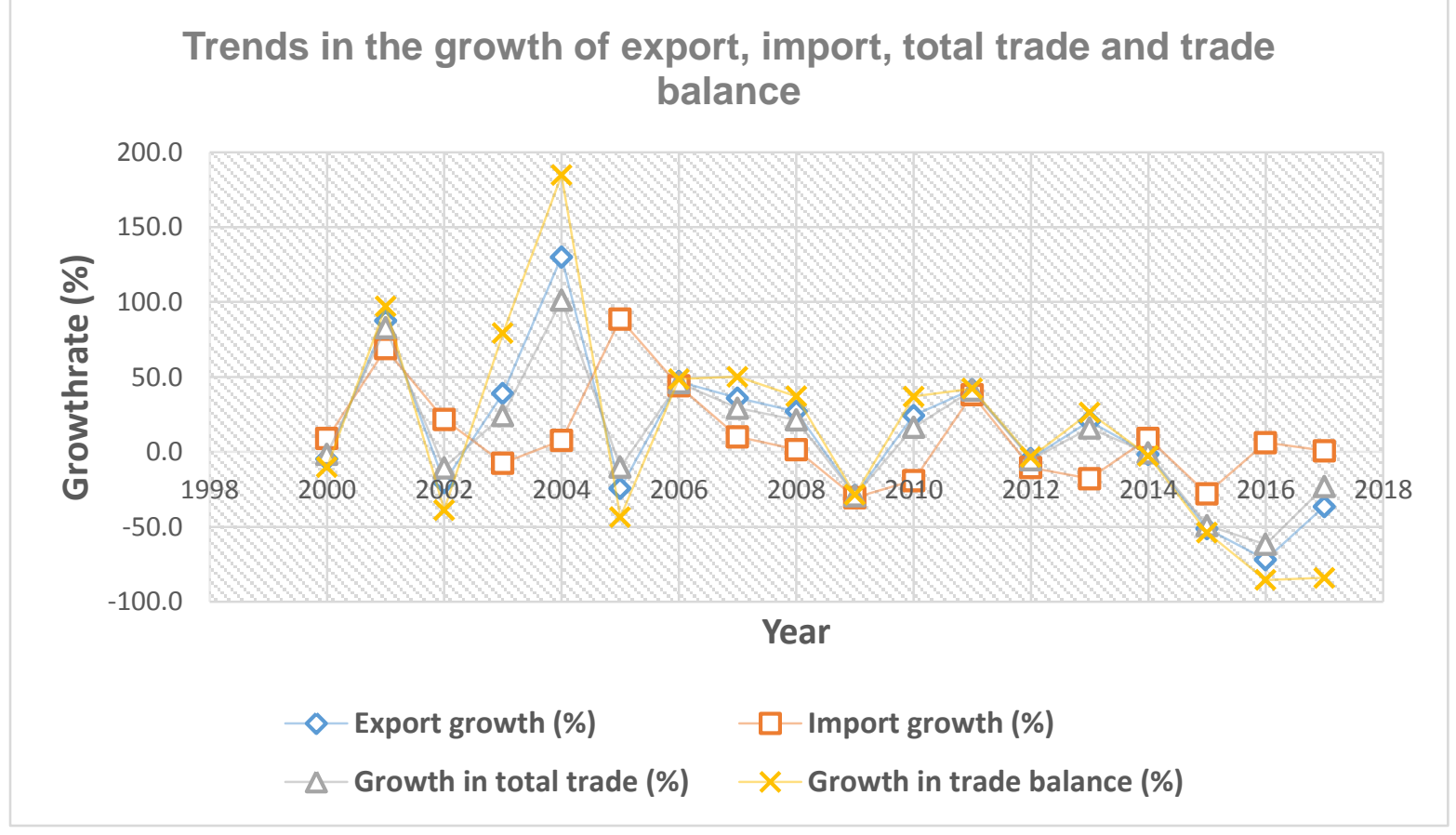

Figure 2: Trends in the growth of Nigeria-Brazil Trade 2000-2017.

Source: Authors' Computation from UNCOMTRADE Statistics dated 21/10/2018.

The trends in the growth rate of Nigeria's export, import, total trade, and trade balance with Brazil are shown in figure 2, which is an indicator of the progress of Nigeria-Brazil trade from 2000-2017. The growth rate of Nigeria's export, import and total trade with Brazil records both rising and falling trends throughout the periods 2000-2017 which is also accompanied by both positive and negative growth. Any major change in the growth of Nigeria's export and total trade with Brazil is as a result of a change in mineral fuel export to Brazil because mineral fuel export dominates Nigeria's export to Brazil. Since 2013 Nigeria's trade with Brazil has not recorded a positive growth this is a result of a decline in export to Brazil from 2013-2017. But the fact is that Nigeria-Brazil trade despite recent decline has recorded a remarkable growth especially from 2001-2011.

\section{b. The composition of Nigeria-Brazil Trade 2000-2017}

There are number products categories that made up Nigeria-Brazil trade possible, these commodities play a vital role in strengthening Nigeria-Brazil trade, the role of these commodities must be investigated in this part of the analysis. The products of interest were chosen based on their performance and contribution to Nigeria's export to Brazil and its import from Brazil. Ten major products categories were selected from UNCOMTRADE database based on 2 digits HS 
categorization of products. It is important to say that these commodities were of strategic importance to Nigeria-Brazil bilateral trade relations.

Table 1

Main Sectors of Nigeria-Brazil Trade 2000-2017

\begin{tabular}{|c|c|c|c|}
\hline $\begin{array}{l}\text { Main exports sectors to } \\
\text { Brazil 2000-2017 }\end{array}$ & $\begin{array}{l}\text { Sectorial share in } \\
\text { total exports to Brazil } \\
2000-2017\end{array}$ & $\begin{array}{l}\text { Main imports sectors } \\
\text { from Brazil 2000-2017 }\end{array}$ & $\begin{array}{l}\text { Sectorial share in total } \\
\text { imports from Brazil } \\
2000-2017\end{array}$ \\
\hline Mineral fuels & 0.99 & $\begin{array}{ll}\text { Sugars and sugar } \\
\text { confectionery }\end{array}$ & 0.34 \\
\hline $\begin{array}{l}\text { Footwear \& parts of such } \\
\text { articles }\end{array}$ & 0.00 & Cereals & 0.23 \\
\hline Oilseed, seed, fruit, etc. & 0.00 & $\begin{array}{l}\text { Vehicles railway tram \& } \\
\text { roll-stock }\end{array}$ & 0.11 \\
\hline Rubber and articles thereof & 0.00 & $\begin{array}{l}\text { Plastics and articles } \\
\text { thereof }\end{array}$ & 0.06 \\
\hline $\begin{array}{l}\text { Tobacco \& manufactured } \\
\text { tobacco }\end{array}$ & 0.00 & $\begin{array}{l}\text { Beverages, spirits, and } \\
\text { vinegar }\end{array}$ & 0.03 \\
\hline Cotton & 0.00 & Organic chemicals & 0.03 \\
\hline Rawhides and skins & 0.00 & Nuclear reactors, boilers, & 0.03 \\
\hline $\begin{array}{l}\text { Ships, boats \& floating } \\
\text { structures. }\end{array}$ & 0.00 & Paper \& paperboard & 0.02 \\
\hline $\begin{array}{l}\text { Plastics and articles } \\
\text { thereof }\end{array}$ & 0.00 & $\begin{array}{l}\text { Salt, Sulphur, earth \& } \\
\text { stone }\end{array}$ & 0.02 \\
\hline $\begin{array}{l}\text { Cocoa and cocoa } \\
\text { preparations }\end{array}$ & 0.00 & Articles of iron or steel & 0.01 \\
\hline
\end{tabular}

Source: Author's own calculation from UNCOMTRADE Statistics dated 22/10/2018.

Share below 0.01 is omitted by rounding up.

Table 1 shows the share of the main products of Nigeria's exports to Brazil to its total exports to Brazil from 2000-2017, together with the share of the main products imported from Brazil to the total imports from Brazil. The share of the main products exported remained negligible except for mineral fuels which account for over 99 percent of Nigeria's exports to Brazil. These sectoral shares are an indication of the poor performance of these sectors to Nigeria's foreign trade. Since over 99 percent of Nigeria's exports to Brazil are made up of mineral fuels, it implies that the Nigerian economy remained undiversified, mono-cultural with non-diversified exports for the whole periods 2000-2017. This finding supported the results obtained in (Ibrahim and Shehu 2016; Ibrahim 2015; Ibrahim and Dilfraz, 2014) studies. The share of import from Brazil remained significant for the whole periods as Sugar and sugar confectionery accounts for 34 percent of Nigeria's total import from Brazil for the periods 2000-2017 followed by cereals with 23 percent and vehicles railway tram and roll-stock 11 percent import share. These import shares are an indication of Brazil's non-mono-cultural economy with well-diversified exports to Nigeria. 
Sectoral share in total exports to Brazil, 2000-2017

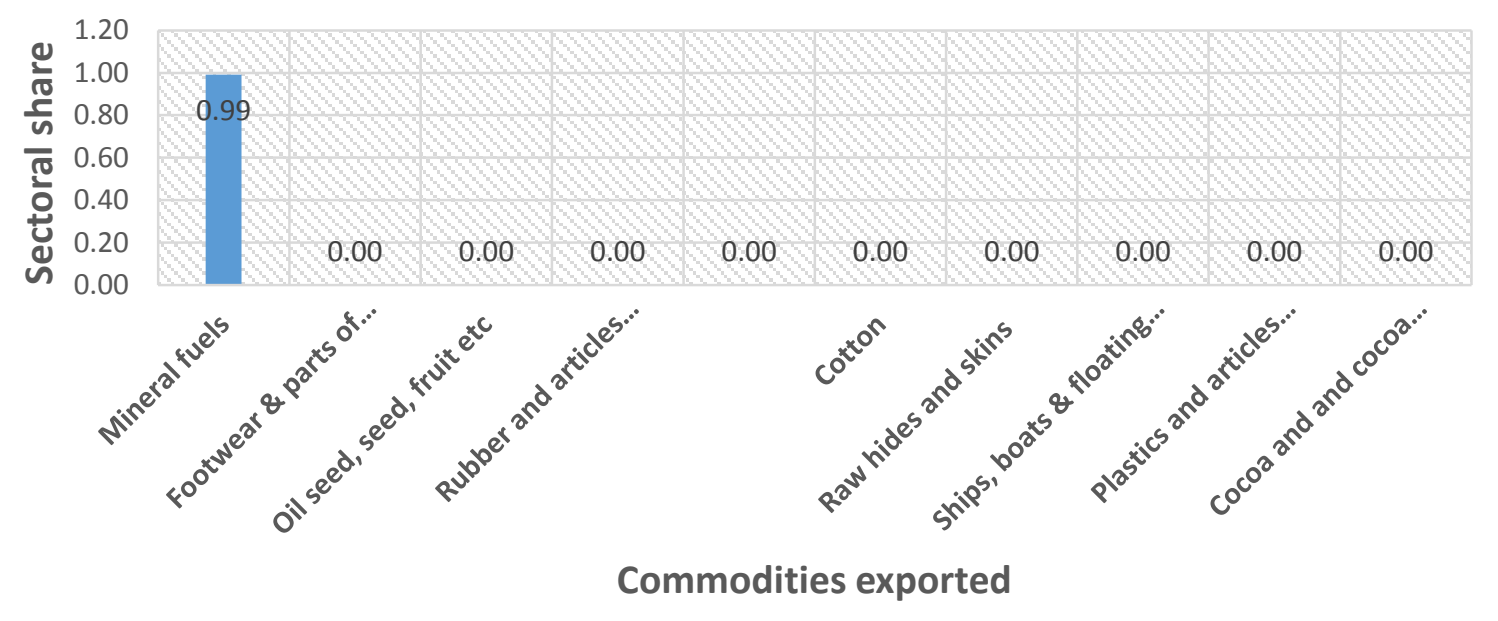

Figure 3: Main exports sectors of Nigeria-Brazil trade, 2000-2017.

Source: Authors' Computation from UNCOMTRADE Statistics dated 22/10/2018.

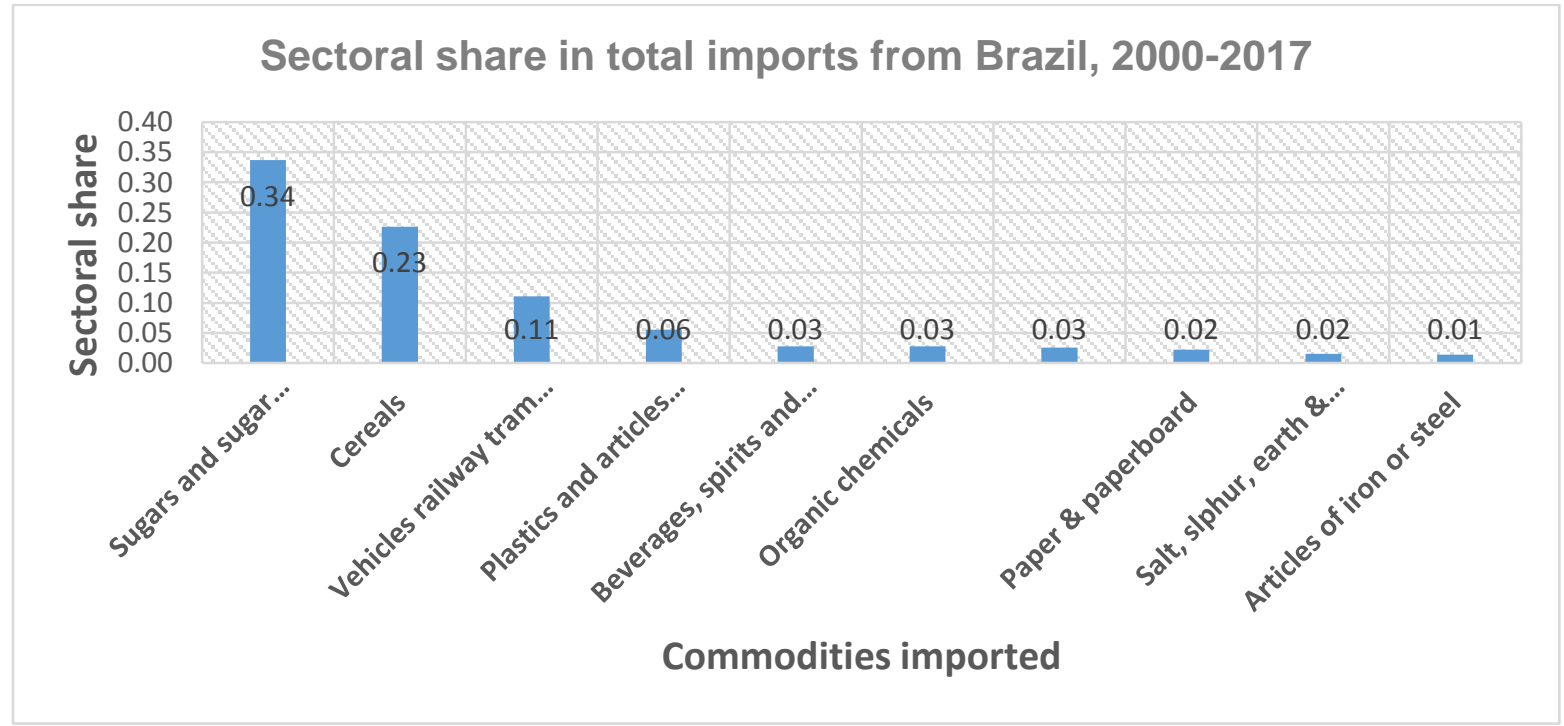

Figure 4: Main imports sectors of Nigeria-Brazil trade, 2000-2017.

Source: Authors' Computation from UNCOMTRADE Statistics dated 21/10/2018.

Figure 3 portrayed the composition of Nigeria's exports to Brazil. The export share of each product category in total exports to Brazil is shown by a scale length of the bar. As can be seen, mineral fuels remained the main export sector to Brazil as it accounts for 99 percent of Nigeria's export to Brazil. The remaining product's categories account for almost zero shares to the total exports to Brazil. However, figure 4 indicates the import share, sugar and sugar confectionery, cereals and vehicles railway tram and roll-stock, plastics and articles thereof remained the dominant of Nigeria's imports from Brazil with a share of 34 percent, 23 percent, 11 percent, and 6 percent respectively from 2000-2017. The remaining products categories shares stood between 1-3 percent from 2000-2017. 
c. Trade Intensity Index 2000-2017

Table 2

Nigeria-Brazil trade intensity index 2000-2017.

\begin{tabular}{|c|c|c|c|c|c|c|}
\hline \multirow[t]{2}{*}{ Year } & Nigeria's & \multirow{2}{*}{$\begin{array}{l}\text { Brazil's TII } \\
\text { with } \\
\text { Nigeria }\end{array}$} & Nigeria's & Brazil's & Nigeria's & Brazil's \\
\hline & $\begin{array}{l}\text { TII with } \\
\text { Brazil }\end{array}$ & & $\begin{array}{l}\text { EII with } \\
\text { Brazil }\end{array}$ & $\begin{array}{l}\text { EII with } \\
\text { Nigeria }\end{array}$ & $\begin{array}{l}\text { III with } \\
\text { Brazil }\end{array}$ & $\begin{array}{l}\text { III with } \\
\text { Nigeria }\end{array}$ \\
\hline 2000 & 2.1 & 2.4 & 2.8 & 4.9 & 3.3 & 2.9 \\
\hline 2001 & 4.8 & 2.7 & 6.5 & 5.5 & 2.2 & 7.8 \\
\hline 2002 & 8.3 & 3.2 & 11.3 & 6.1 & 2.1 & 7.5 \\
\hline 2003 & 8.0 & 2.4 & 10.6 & 3.2 & 1.2 & 9.2 \\
\hline 2004 & 6.2 & 2.1 & 7.9 & 2.7 & 1.4 & 13.2 \\
\hline 2005 & 5.1 & 3.0 & 6.6 & 4.1 & 1.5 & 7.3 \\
\hline 2006 & 4.4 & 3.7 & 5.5 & 5.2 & 1.6 & 8.1 \\
\hline 2007 & 5.9 & 3.0 & 7.3 & 4.0 & 2.8 & 10.4 \\
\hline 2008 & 4.9 & 2.0 & 6.0 & 4.3 & 1.3 & 7.0 \\
\hline 2009 & 6.2 & 1.8 & 7.6 & 2.5 & 2.5 & 8.6 \\
\hline 2010 & 4.6 & 1.2 & 5.8 & 1.4 & 2.3 & 5.3 \\
\hline 2011 & 5.3 & 1.2 & 6.6 & 1.3 & 3.6 & 4.9 \\
\hline 2012 & 4.6 & 1.3 & 5.9 & 2.1 & 5.4 & 4.1 \\
\hline 2013 & 5.9 & 1.0 & 7.0 & 1.4 & 2.0 & 7.5 \\
\hline 2014 & 6.3 & 1.3 & 5.3 & 1.4 & 1.6 & 5.5 \\
\hline 2015 & 6.0 & 1.4 & 4.9 & 1.7 & 1.1 & 5.2 \\
\hline 2016 & 4.8 & 1.0 & 3.4 & 1.6 & 1.3 & 4.0 \\
\hline 2017 & 3.6 & 1.1 & 2.2 & 1.2 & 1.3 & 3.6 \\
\hline
\end{tabular}

Source: Author's own calculation from UNCOMTRADE Statistics dated 23/10/2018.

The relative importance of Brazil to Nigeria and the relative importance of Nigeria to Brazil is measured by their trade intensities. Based on these trade indices Nigeria and Brazil trade is greater than expected to be on the basis of their relative importance in the world trade and there is a greater possibility of increasing Nigeria-Brazil bilateral trade and the reason for this high trade intensity is a result of the fact that both Nigeria and Brazil are developing countries with high population and emerging market. 


\section{Trends in Nigeria-Brazil trade intensity $\mathbf{2 0 0 0 - 2 0 1 7}$}

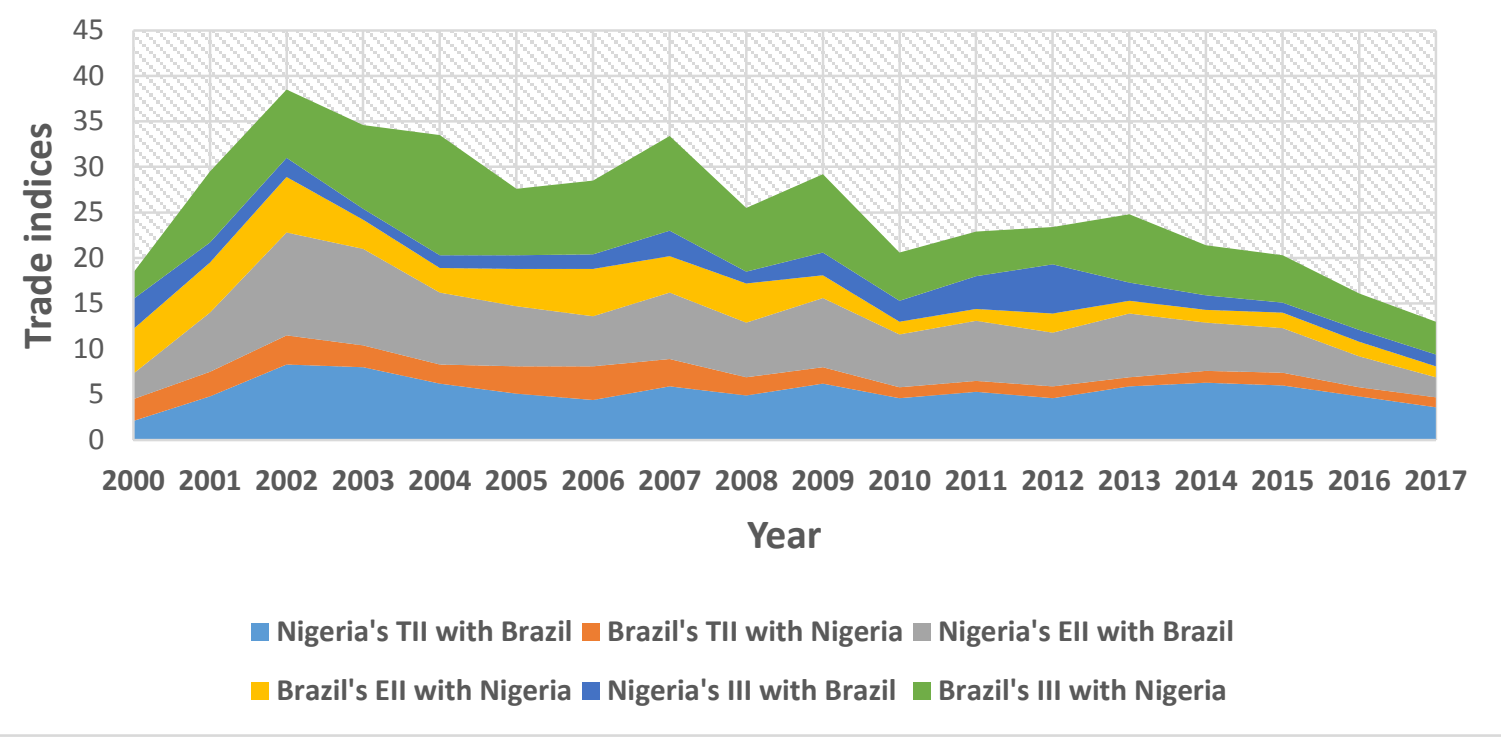

Figure 5: Trends in Nigeria-Brazil trade intensity 2000-2017.

Source: Authors' Computation from UNCOMTRADE Statistics dated 23/10/2018.

In Figure 5, the trends in Nigeria-Brazil trade intensity are depicted. The trends in trade intensity are shown in the first two shaded areas and the trends move within the range of 1 to 8.3 index of both Nigeria and Brazil throughout the periods 2000-2017. The trends graph is enough to shows the benefit of trade balance which both countries have as a result of bilateral trade, in the first place the area under the graph line of Nigeria's trade intensity with Brazil exceeds that of Brazil with Nigeria, which again is an indication of more export possibility to Brazil by Nigeria and vice versa. The trends in export and import intensity explains the same thing of which the area under Nigeria's export intensity with Brazil exceeds that of Brazil with Nigeria and this is a good reflection that Nigeria exports more than it imports from Brazil throughout the periods 20002017 and the balance of trade is in favor of Nigeria. For import intensity trends the area under trend line of Nigeria's import intensity with Brazil is lower than that of Brazil's import intensity with Nigeria as a result, Brazil imports more goods from Nigeria which are mostly mineral fuels. As the figure shows the trends in trade intensities has both a rising and falling trend.

\section{CONCLUSION AND POLICY RECOMMENDATIONS}

This study empirically examined the trends, composition and trade intensity of Nigeria-Brazil trade for the period of 2000-2017. Nigeria's trade with Brazil has recorded a significant increased from 2000-2014 despite the major declined from 2015-2017. Nigeria exports more than it imports from Brazil throughout the periods 2000-2017 as such the balance of trade have been in favor of Nigeria. In spite of the recent decline in trade, bilateral trade between the two countries has recorded a remarkable growth especially from 2001-2011. The share of major products exported to Brazil remained negligible except for mineral fuels which account for over 99 percent of the total export. The result from the trade indices indicates that Nigeria and Brazil 
trade is greater than expected on the basis of their relative importance in the world trade and there is a greater possibility of increasing Nigeria-Brazil bilateral trade. The trends movement in trade, export, and import intensity clearly indicate the trade balance which has been in favor of Nigeria.

On the basis of these findings, the study recommends the need for the government to encourage export toward promoting bilateral trade between the countries this is because both countries are characterized by large markets, teaming and growing population. This is an indication of high capacity for Nigeria to produce and for Brazil to absorb Nigeria's export supply and vice versa. The results also suggest the need to restructure Nigeria's export in order to reduce the prevailing role of mineral fuels to Nigeria's exports. This can be achieved by diversifying the Nigerian economy, this is because by given emphasis to the non-oil potential sectors of the economy trade volume would be expected to increase. The measure of bilateral trade relations also shows evidence of high trade intensity between Nigeria and Brazil, in this regard, there is the need for government, researchers, and export promotion agencies to identify new opportunities for Nigeria's exports in the Brazilian market. This will help in diversifying the Nigerian economy and strengthening trade relations between the countries.

\section{References}

Abiodun, A. (2011a). Nigeria and the Global Powers: Continuity and Change in Policy and Perceptions. African perspectives. Global insights. 1-28. Retrieved December 20, 2017

Abiodun, A. (2011b). Nigeria and the BRICs: Diplomatic, Trade, Cultural and Military Relations. South African Institute of International Affairs. Retrieved December 20, 2017.

Abraham, O. A., and A. G. Adekola, (2014). Regional Economic Integration in Developing Countries: A Case Study of Nigeria: A Member of ECOWAS. European Scientific Journal, 10(19): 359-374.

Garrick, K., (2013). "Bilateral Business between Nigeria and Brazil: The Way Forward". Retrieved August 8, 2015, from http://www.vanguardngr.com/2013/08/nigeria-braziltrade-below-volume-potential/

Ibrahim, K. H., (2015). Trade Complementarity and Similarity between Nigeria and India in the context of Bilateral Trade Relations. IOSR Journal of Economics and Finance (IOSR$J E F)$, 4(4), 28-32. Doi: 10.9790/5933-06642832

Ibrahim, K. H., and S, Dilfraz, (2014). Changing Perspective of Indo-Nigerian Trade Relations. Indian Journal of Applied Research, 4(7), 497-503. Doi: 10.15373/2249555X

Ibrahim, K. H., and A. S. Sayuti, (2017a). Nigeria's Export Supply versus Brazil's Import Demand: 2000-2016. LIfe Social Sciences Review, 25(2), 48-58.

Ibrahim, K. H., and A. S. Sayuti, (2017b). Nigeria's Trade Complementarity and Similarity with West African Sub-Region. Benue Journal of Social Sciences, 5(1), 122-138.

Ibrahim, K. H., and A. Shehu, (2016). Nigeria-India Bilateral Trade Relations: An Analysis of Trade Complementarity Index (TCI). Asian Journal of Economic Modelling, 4(4), 190198. doi:10.18488/journal.8/2016.4.4/8.4.190.198. 
Ibrahim, K. H., and P. T. Iorember, (2018). Sectoral and Products Wise Comparative Advantage in Nigeria-China Bilateral Trade Relations. Dutse Journal of Economics and Development Studies (DUJEDS), 6(1): 2536-6130.

Idris, A., and O. Chukwuka, (2014). Nigeria-Poland Bilateral Trade: Identifying New Trade Opportunities. Centre for the Study of the Economies Africa. Retrieved November 7, 2015.

International Monetary Fund, (2018). Report for Selected Countries and Subjects. Retrieved October 20 , 2018 , https://www.imf.org/external/pubs/ft/weo/2018/01/weodata/weorept.aspx?

Loius, C. N., and A. O. Adewuyi, (2012). Dynamic of Trade between Nigeria and other ECOWAS Countries. Retrieved December 19, 2017, from http://www.brookings.edu/ /media/Research/Files/Reports/2012/1/intra-Africantrade/01_nigeria_trade.PDF

Mombert, H., and A. Francic, (2012). Removing Barriers to Trade between Ghana and Nigeria: Strengthening Regional Integration by Implementing ECOWAS Commitments. World Bank. Retrieved December 20, 2017, from www.worldbank.org/afr/trade

Mthuli, N., L. L. Charles, and V. Desire, (2011). Brazil's Economic Engagement with Africa. African Development Bank Group Chief Economist Complex. Retrieved November 24, 2015.

Ogunkola, O. E., (1998). An Empirical Evaluation of Trade Potential in the Economic Community of West Africa States. African Economic Research Consortium.

Rakesh, M. J., N. Biswajit, and G. Ashish, (2012). India's Export Opportunity in Africa: Issues and Challenges in Select Sectors. Indian Institute of Foreign Trade. Retrieved December 20, 2017.

Sabyasachi, T., and C. L. Nuno, (2013). India's Trade and Gravity Model: A Static and Dynamic Panel Data. Munich Personal RePEc Archive. Retrieved from http://mpra.ub.unimuenchen.de/45502/

Sunanda, S., (2010). International Trade Theory and Policy: A Review of the Literature*. Levy Economics Institute of Bard College.

Uncomtrade, (2016). World Integrated Trade Solution (WITS). Retrieved October 23, 2018, from World Integrated Trade Solution (WITS): http//comtrade.un.org/dbBasicQuery.aspx.

Vincent, A. O., 2013. Nigeria-Brazil business relations: the journey so far speech delivered by the Nigerian Ambassador to Brazil. Retrieved January 27, 2016, from http://www.nigerianembassy-brazil.org/ingles/News/noticia_01.htm

Walther, O., Tenikue, M., and K. Mathias. (2012). Regional trade and border markets between Niger, Benin, and Nigeria: A methodological note. Luxembourg: CEPS/INSTEAD. 